UC.70

Issued: October 1982

LA $-9326-\mathrm{HS}$

DE83 003990

\title{
Aspects of Possible Magmatic Disruption of a High-Level Radioactive Waste Repository in Southern Nevada
}

\author{
Bruce Crowe \\ Robert Amos* \\ Frank Perry \\ Stephen Self* \\ David Vaniman
}



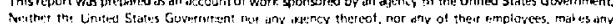

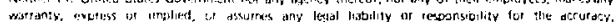

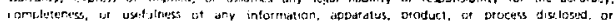

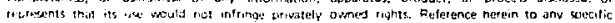

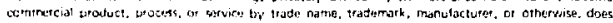

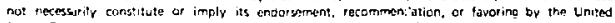

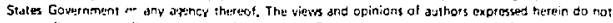


ASPECTS OF POSSIBLE MAGMATIC DISRUPTION OF A HIGH-LEVEL RADIOACTIVE WASTE REPOSITORY IN SOUTHERN NEVADA

by

Bruce Crowe, Robert Amos, Frank Perry, Stephen Self, and David Vaniman

\section{ABSTRACT}

The Nevada Test Site (NTS) region is located within the central section of a north-northeast-trending basaltic volcanic belt of late Cenozoic age, a part of the Quaternary volcanic province of the Great Basin. Future volcanism within the belt represents a potential hazard to storage of high-level radioactive waste within a buried repository located in the southwestern NTS. The hazards of future volcanism in the region are being characterized through a combination of volcanic hazards studies, probability determinations, and consequence analyses. Basaltic activity within the NTS regions is divided into two age groups consisting of relatively large-volume silicic cycle basalts ( 8 to 10 Myr) and rift basalts ( $<8$ to 0.3 Myr). The rift basalts occur as small-volume $\left(<0.1 \mathrm{~km}{ }^{3}\right)$ spatially separate basaltic centers. The lavas are classified as hawaites and show strong affinities to the alkalic basalt suite. They were derived from the upper mantle below a depth of 30 to $35 \mathrm{~km}$ and were modified from parental compositions by crystal fractionation. Younger rift basalts (<4 Myr) are enriched in incompatible trace elements. Theoretical and geological considerations of basalt rise rates indicate rapid ascent of basalt (tens of centimeters per second) within the bubble-free regime. Rising basalt magma is probably trapped at the crust/mantle density interface. The magma probably crystallizes high-density phases (olivine, pyroxene) that decrease the liquid density due to crystal removal (Stolper and Walker 1980). As the density decreases, the magma re-initiates rapid ascent through the crust. Field studies and geometrical arguments suggest that basalt centers are fed at depth by narrow, linear dikes (aspect ratio $10^{-2}$ to $10^{-1}$ ). However, in some cases, shallow intrusions are formed (Piaute Ridge and Nye Canyon area of the NTS). These intrusions probably formed through a combination of factors during emplacement, including extension faulting, development of a fluid yield strength due to the relatively high crystal content of the magna, and trapping by low-density tuff as a result of low magma-volatile content. Surface basalts comprise single or 
coalesced scoria cones of moderate size with associated lava flows. Eruptions were predominantly of Strombolian type. The rise rate of basalt magma for these centers was probably toward the low range of typical basalt rise rates, based on their ratios of cone volume to lava volume and their short lava lengths. Potential dispersal pathways of radioactive waste incorporated and dispersed through Strombolian eruptions are traced, assuming magma intersects a repository at depth. These dispersal pathways require that waste elements are incorporated and transported in basalt magma in a manner similar to lithic fragments. Such fragments are probably engulfed during magma disruption and fragmentation and are partitioned preferentially in the pyroclastic component of an eruption. Assuming a future magmatic cycle that is similar in volume to that of the Lathrop Wells cone of the NTS region, $54 \mathrm{~m}^{3}$ of material from a repository horizon will be deposited in a scoria cone (of which $2.7 \mathrm{~m}^{3}$ will be exposed at the surface in a 10 000-year period), 96 to $245 \mathrm{~m}^{3}$ will be incorporated in a scoria sheet (2 to $12 \mathrm{~km}$ dispersal) and $6.1 \mathrm{~m}^{3}$ will be dispersed regionally with the fine-grained particle fraction (>12 km dispersal).

\section{INTRODUCTION}

The Nevada Test Site (NTS) region is cut obliquely by a late Cenozoic basaltic volcanic belt that extends from southern Death Valley northnortheastward to central Nevada (Crowe et al. 1980). The geologic history and petrology of basaltic volcanism within this belt are under study to assess the potential hazards of future volcanism with respect to siting of a repository for permanent storage of high-level radioactive waste within the NTS. Hazard assessment as applied to waste storage includes several phases. These are the identification of processes that could result in failure of a waste-isolation system through deterministic geologic studies, the calculation of the probability of occurrence of identified processes, and the calculation of consequences due to failure of a waste-isolation system by such processes. Failure is generally expressed as rates or concentrations of released waste elements.

Probability calculations were determined following identification of volcanism as a potential disruptive event for the geologic setting of the NTS region. Crowe and Carr (1980) calculated an annual probability of repository disruption on the order of $10^{-8}$ to $10^{-9}$. Crowe et al. (1982) further refined 
the probability calculations using two procedures to establish rates of volcanism and constraining the areal dimensions of the calculations by the distribution of volcanic centers of Quaternary age in the southern Great Basin. They note that the probability values are bounded by the range $10^{-8}$ to $10^{-10}$ /year but note that interpretations of the values are limited by the geologic assumptions necessary to allow the calculations.

Due to the uncertainties of probability calculations and pending establishment of acceptable or unacceptable probability limits for volcanic risk assessment, studies are underway to determine the direct consequences of disruption of a repository by volcanic activity. This requires several types of data. First, the expected composition of future volcanism needs to be defined. Geologic studies of the NTS region (Crowe and Sargent 1979; Crowe and Carr 1980) indicate that the most probable composition of future volcanism is basaltic. Basalt has been the only magma type erupted at the surface in the NTS region during the last $7.0 \mathrm{Myr}$. Moreover, fundamentally basaltic volcanism has been the dominant magma type within the Great Basin and much of the western United States since 10 Myr ago (Christiansen and Lipman 1972; Stewart and Carlson 1978; Best and Hamblin 1978). Second, the volcanic processes that may directly result in dispersal of waste elements, should basalt magma intersect a repository, need to be defined. These include, for example, the nature of basalt intrusions, rates of ascent of magmas, and surface eruption mechanisms.

This paper describes the processes of basaltic magmatism ranging from derivation of basalt melts at depth, through ascent through the upper mantle and crust, to surface eruption. Each stage in the evolution and dispersal of basaltic magma is described, and the disruption and potential dispersal of stored radioactive waste is evaluated. These data document areas of knowns and unknowns in the processes of basaltic volcanisms and provide background data necessary to assist calculations of radiation release levels due to disruption of a repository (Logan et al. 1982).

\section{BASALTIC VOLCANISM OF THE NTS REGION}

Basaltic volcanic rocks of Late Miocene age and younger crop out at scattered localities within the NTS region (Fig. 1). Basalt centers of Pleistocene age are present within Crater Flat, adjacent to the southeast edge of Crater Flat, and adjacent to the western edge of the Sleeping Butte cauldron 




Fig. 1 .

Distribution of basaltic volcanic rocks in the NTS region. TM-OV: Timber Mountain-0asis Valley caldera complex; SC: Silent Canyon cauldron; BM: Black Mountain caldera complex; YM: Yucca Mountain exploration block; dark stippled pattern: outcrop area of the silicic cycle basaltic rocks; 1ight stippled pattern and star symbols: post-silicic cycle basalts including, in order of increasing age-LW: basalt of Lathrop Wells; SB: basalt of Sieeping Butte; CF: 1.1-Myr basalt of Crater Flat; BB: basalt of Buckboard Mesa; CF: 3.7-Myr basalt of Crater Flat; NC: basalt of Nye Canyon; PR: basalt of Paiute Ridge; SCR: basalt of Silent Canyon ring fracture zone. Numbers are approximate age of basalt centers in million years.

segment of the Timber Mountain-0asis Valley cauldron complex. Basalts of Pliocene age crop out within the moat zone of the Timber Mountain cauldron and 
the southcentral and southeastern parts of Crater Flat. Aeromagnetic data suggest the presence of several buried basalt centers of presumed Pliocene age. These occur immediately south of Lathrop Wells and beneath Crater Flat (Crowe and Carr 1980). Basaltic volcanic rocks of Miocene age were erupted during the waning stages of voluminous silicic volcanic activity associated with the Timber Mountain-Oasis Valley caldera complex (Byers et al. 1976; Christiansen et al. 1977). The basalts generally occur within and along the flanks of the major silicic centers. By contrast, younger rift basalts, which are the major components of the volcanic belt, are spatially separate and younger than the large-volume silicic volcanic centers of the NTS region (Fig. 1). The rift basalts occur as small-volume $\left(<1-\mathrm{km}^{3}\right)$ centers at scattered localities. Geochronology studies (Crowe and Carr 1980; Carr et al. 1982) show that the basalt centers were active during generally synchronous pulses or cycles that were of short duration and distributed sporadically in time. The basalts are structurally associated with $\mathrm{N}$-NE-trending zones of extension between $\mathrm{N}$-NW-trending right-slip faults, ring-fracture zones of caldera complexes, and basin-range faults. The following sections of the paper are concerned with the rift basalts, the predominant type of surface volcanic activity in the NTS region during the last 8 Myr.

\section{BASALT COMPOSITIONS AND ORIGINS}

The main volume of the Plio-Pleistocene rift basalts of the NTS region are of hawaite composition. The most carefully studied basalts are the 0.3to 3.7-Myr basalts of Crater Flat (Vaniman and Crowe 1981). The term hawaiite became widely used in the basin-range with the work of Best and Brimhall (1974). This rock suite is now recognized as an important magmatic constituent of volcanic rocks of anorogenic continental settings (Ewart et al. 1980). For samples from this region, the term hawaiite is used for basalts with the following characteristics:

(1) normative plagioclase An content between 30 and $52 \mathrm{~mol} . \%$,

(2) relatively evolved compositions with $\mathrm{Mg} /(\mathrm{Mg}+\mathrm{Fe})<0.6$, and

(3) transitional alkalic affinities that encompass both nepheline- and hypersthene-normative compositions.

Lavas with these characteristics are the major late Cenozoic magma types throughout an area extending from the central to southeastern Great Basin (Lowder 1973; Best and Brimhall 1974; Best and Hamblin 1978). Mineralogically 
these lavas show strong affinities to the alkalic basalt suite (Yoder and Tilley 1962). They are sparsely to moderately porphyritic with phenocryst assemblages dominated by magnesium olivine and to a lesser degree plagioclase. Pyroxenes, which occur in subordinate amounts as phenocrysts and in the groundmass, are uniformly $\mathrm{Ca}$ rich. Ca-poor pyroxene is present in the groundmass of only a few samples (Lowder 1973; Vaniman and Crowe 1981). The basalts of Crater Flat are both nepheline- and hypersthene-normative and follow the Straddle-A classification of Miyashiro (1978). Less evolved members of the basalt field straddle the dividing line between the nepheline- and hypersthene-normative field, and more evolved members project into the nepheline or hypersthene fields (Vaniman et al. 1982).

Variations in incompatible trace elements for differing cycles of the basalts of Crater Flat of the NTS region require fractionation of olivine + clinopyroxene \pm kaersutite (during 1.2- and 0.3-Myr eruptions) or by olivine + minor clinopyroxene (3.7-Myr eruptions). The isotopic data of Leeman (1974) indicate a mantle source of long-standing $\mathrm{Rb}$ enrichment in order to generate the high ${ }^{87} \mathrm{Sr} /{ }^{86} \mathrm{Sr}$ ratios in late Cenozoic basalts of Crater Flat. Based on a single-stage $\mathrm{Rb}$ enrichment model and the highest $\mathrm{Rb} / \mathrm{Sr}$ content among the 3.7-Myr basalts, this initial Rb enrichment may have occurred more than 900 Myr ago. Moreover, data from the younger basalt cycles $(0.3$ and $1.7 \mathrm{Myr})$ suggest that their mantle source regions were enriched recently in Sr. This $\mathrm{Sr}$ enrichment was accompanied by a striking increase in the trace-element contents of basalts younger than $4 \mathrm{Myr}$ in the NTS region. The downward adjustment of $\mathrm{Rb} / \mathrm{Sr}$ ratios could be attributed to fluxing of the mantle by aqueous volatile-rich fluids, for $\mathrm{Sr}$ and other large-ion or high-charge incompatible elements can be held in common accessory minerals (amphibole, apatite, and perovskite), whereas Rb may not.

The origin of basaltic suites of the NTS region, and of the Great Basin in general, have been considered by a number of workers. Hedge and Noble (1971) note that basalts of the southern Great Basin have consistently high initial ${ }^{87} \mathrm{Sr} /{ }^{86} \mathrm{Sr}$ ratios (average about 0.707 ) and high strontium contents (average $1200 \mathrm{ppm}$ ). The $\mathrm{Rb} / \mathrm{Sr}$ contents of these basalts are too low to generate the high isotopic ratios, and the low Rb contents of the basalts may rule out crustal contamination. Hedge and Noble suggest that the basalts were generated from mantle material that once had a high $\mathrm{Rb} / \mathrm{Sr}$ ratio, and that ratio was lowered by some event prior to their eruption. Best and Brimhall 
(1974) model the generation of hawaite magma by relatively large degrees of partial melting of mantle peridotite (at depths $<65 \mathrm{~km}$ ) followed by polybaric fractionation. They suggest the hawaite compositions and absence of ultramafic inclusions require slow or possibly interrupted ascent to the surface (Best and Brimhall 1974, p. 1685). Leeman (1974) examined isotopic compositions of basalt from a number of areas in the eastern Great Basin; his results support the model of Best and Brimhall for generation of hawaite and related rocks: independent partial melts of mantle through a range of pressures, followed by fractionation during ascent.

The depth of the low-velocity zone near Crater Flat places minimum limits on the depths of basaltic magma genesis. The parent magmas must be derived at depths lower than the base of the crust at $31 \mathrm{~km}$ (Prodeh1 1970; 1979), but these data provide no constraints on maximum depth of origin. Best and Brimhall (1974) suggest a maximum depth of $65 \mathrm{~km}$ for parent compositions that may lead to hawaite magma. This depth is loosely constrained by the composition of four-phase mantle assemblages at high pressure. Modification of parental compositions by fractionation prior to eruption is required by the data of Best and Brimha11 (1974) and Vaniman and Crowe (1981).

\section{MECHANISM AND RATE OF ASCENT OF BASALT MAGMA}

Assuming generation of basalt magma in the upper mantle $(30$ to $65 \mathrm{~km}$ ) by partial melting, we next examine the mechanics and rate of magma ascent to the surface. This section is concerned particularly with the form of magma ascent at depths $>5 \mathrm{~km}$; magma intrusion in the upper crust is discussed in a following section. A slow rate of rise of magma (on the order of meters per year) requires thousands of years for melt to ascend from mantle depths to the surface. This provides time for magmatic fractionation with possible derivation of a range of magma types (basaltic to silicic) and thermal equilibration of magma with country rock. More importantly, it provides significant lag time, the period between closure of a waste repository and disruption by volcanism (Crowe 1980). The longer the lag time, the less severe the consequences of repository disruption due to the exponential radioactive decay of waste elements. Slow rise rates are typically inferred for large-volume, dome-like bodies of granitic magma (for example, Ramberg 1968). These may be detectable at depth through detailed geophysical studies. A rapid rate of 
rise of magma (centimeters per second) requires ascent to be near instantaneous in comparison to the duration of isolation of radioactive waste. There is little chance of detection of such events prior to surface eruption.

Rise rates of basaltic magma have been calculated by a number of workers using a variety of approaches; the subject has been reviewed most recently by Wilson and Head (1981). Basalt magma at depths greater than $\mathrm{s} 2 \mathrm{~km}$ is gas free and therefore the rise of magma is driven primarily by the density difference between magma and the crustal column. For low Reynolds numbers, Wilson and Head (1981) describe the velocity of magma rise $\left(V_{m}\right)$ :

$$
v_{m}=\frac{8 g r^{2}\left(\rho_{c}-\rho_{m}\right)}{A_{n}} \text {, }
$$

where $g$ is the acceleration due to gravity, $r$ is the dike width, $\rho_{c}$ is the density of the crustal column, $\rho_{m}$ is the magma density, and $\eta$ is the magma viscosity. In the case of basalt magma with appreciable yield strength (non-Newtonian or Bingham flow), the velocity equation becomes (Wilson and Head 1981):

$$
v_{m}=\frac{8 r^{2}}{A n} \quad\left\{g\left(\theta_{c}-\theta_{m}\right)-B \frac{S y}{r}\right\} .
$$

where Sy is the yield strength and $A$ and $B$ are dimensioniless numbers for cases of conduit and fissure flow. Wilson and Head (1981) sugges that Eqs. (1) and (2) provide two governing cases for the rise of basalt magma, the first where rise of magma is controlled by rate of cooling and therefore by magma viscosity (Eq. 1) and the second where rise is limited by yield strength (Eq. 2). Magma viscosity values are reasonably well known whereas doubt remains whether basalt magmas have appreciable yield strength. Sparks and Pinkerton (1978) and Pinkerton and Sparks (1978) argue that lavas may become non-Newtonian at subliquidus temperatures as a result of degassing and crystallization. This suggestion is supported by the observation that basalt lavas can cease flowing on inclined surfaces (Wadge 1980). However, at mantle and crustal depths, where magma temperatures are higher and viscosity lower (Kushiro 1980), magma movement may be Newtonian. For this reason, the viscosity equation is assumed to be the most valid for flow at depth.

Wilson and Head (1981) have suggested that minimum rise rates and conduit widths may be constrained by magma cooling time and depth of magma source. 
This allows calculation of rise rates as a function of magma viscosity and depth of magma source (Wilson and Head 1981, Table 2). Assigning an average dike width $(2 \mathrm{~m})$ based on studied dikes of the NTS region, a depth to magma source of $40 \mathrm{~km}$, and using the cooling rate calculation (Wilson and Head 1981):

$$
v_{c t}=\frac{4 X \beta^{2} H}{r^{2}} \text {, }
$$

where $X$ is the thermal diffusivity, $\beta$ is a dimensioniess number, and $H$ is the depth of the magma source, gives a minimum rise rate of $1.2 \mathrm{~cm} / \mathrm{sec}$. This is the rate necessary to allow rise of magma from depth without cooling prohibiting eruption. Similarly, rise rates can be determined as a function of conduit width and mass eruption rate. Rise rates ranging from 0.4 to $6.8 \mathrm{~m} / \mathrm{sec}$ can be calculated with associated conduit widths of 0.7 to $3.0 \mathrm{~m}$ and mass eruption rates of $10^{3}$ to $10^{5} \mathrm{~kg} / \mathrm{sec}$ (Wilson and Head 1981, Table 3). For fissure eruptions with similar dike widths and mass eruption rates, rise rates range from 0.8 to $14.6 \mathrm{~m} / \mathrm{sec}$. Based on the relatively small volumes and inferred low eruption rates for the basalts of the NTS region (discussed in a later section), the lower rise rates are probably more appropriate.

Fedotov (1978) calculated magma ascent rates based primarily on thermal constraints and as a function of dike width and depth of source. Appropriate minimum ascent rates for basalts of the NTS region, following his procedures (Fedotor 1978, Fig. 3), are on the order of 3 to $6 \mathrm{~cm} / \mathrm{sec}$; similar ascent values were calculated for the northern and southern Tolbachik eruptions (Fedotov 1978). Spera (1980) reviewed the rates of magma transport by crack propagation and assumed they are 1 imited by the velocity of fracture propagation. He sites slow crack-propagation rates from Anderson and Grew (1977) on the order of $10^{-1}$ to $10^{2} \mathrm{~cm} / \mathrm{sec}$. A number of authors have calculated ascent velocities based on transport of high-density xenoliths, assuming the net upward velocity has to exceed the terminal settling velocity of the fragment within its magma host. Such calculations are dependent on the rhelogical properties of basalt, which in turn are dependent on temperature and the mechanism of flow (laminar or turbulent). Carmichael et al. (1977) calculated a terminal settling velocity of $91 \mathrm{~cm} / \mathrm{sec}$ for a xenolith in basalt, based on the particle Reynolds number and the particle drag coefficient for settling through a Newtonian fluid, governed by Stokes Law. However, Sparks et al. (1977) argue that basaltic melts behave as a non-Newtonian Bingham substance and have yield strengths in the range of 70 to $450 \mathrm{~N} / \mathrm{m}^{2}$. Such yield strengths 
may prohibit the settling of xenoliths of small size and greatly slow the terminal velocities as compared to Newtonian melts. The authors suggest, based on the effects of yield strength, that the presence of nodules does not necessarily imply fast rates of ascent. However, their measured yield strengths are from crystal-rich lavas (Etna and Hawaii) that may be undercooled below their liquidus temperature. The yield strength is strongly dependent on the degree of undercooling below the liquidus temperature, the history of eruption degassing, and crystal content (Shaw 1969; Johnson and Pollard 1973; Sparks and Pinkerton 1978). It is possible that yield strengths of basalt lavas, particularly xenolith-bearing lavas, may range from negligible to values lower than those suggested by Sparks et al. (1977). Spera (1980) has calculated nodule settling velocities based on assumed yield strengths on the order of 10 to $10^{2} \mathrm{~N} / \mathrm{m}^{2}$. For a xenolith to settle through a Bingham melt, it must obtain a minimum density difference or size governed by the equation (Spera 1980);

$$
r^{*}=3 K_{\sigma} / 4 \Delta \rho g
$$

where $r^{\star}$ is the minimum radius, $k$ is a dimensionless constant, $\sigma$ is the yield strength, $\Delta p$ is the density difference between melt and xenolith, and $g$ is the acceleration due to gravity. Modifying the settling equation with the minimum xenolith radius yields (Spera 1980):



where $\mu \pi$ is the xenolith settling velocity; ol is the magma density; and on, $\eta$, and $R n$ are respectively xenolith density, magma viscosity, and the xenolith radius. Calculated xenolith settling rates in basaltic magmas, based on assigned yield strengths and varying values of $r^{*}$, are on the order of 10 to $50 \mathrm{~cm} / \mathrm{sec}$ (Spera 1980, Table 5).

Moore and Krivay (1964) obtained maximum flow velocities for the subsurface movement of magma during two eruption events at Kilauea Volcano, Hawaii. Based on the first occurence of harmonic tremor (source assumed to be at the magma reservoir) and the first appearance of magma at the surface, they calculated magma flow velocities of 38 and $39 \mathrm{~cm} / \mathrm{sec}$. Brandsdottir and Einarsson (1979) obtained two related velocity measurements of subsurface movement of 
magma from the September 1977 eruption of Krafla central volcano in northeastern Iceland. A southward migration of earthquake activity along a major rift zone during a 5-hour period was attributed to movement of magma. The time delay was measured between the onset of detectable harmonic tremor that probably emanated from a subsurface reservoir at a depth of $3 \mathrm{~km}$ and the appearance of magma at the surface. Both were related events and yield subsurface magma movement rates of about $50 \mathrm{~cm} / \mathrm{sec}$. Similarly, Bjornsson et al. (1979) cite a velocity of magma migration of $50 \mathrm{~cm} / \mathrm{sec}$ from the summit area of Krafla Volcano south-southwest to Namofjall during the April 1977 eruption.

In summary, magina rise rates, as determined through a variety of approaches, range from as $10 \mathrm{w}$ as $1 \mathrm{~cm} / \mathrm{sec}$ to several meters per second. Magma rising directly from $35 \mathrm{~km}$ to the surface would require a time period of s4 days at an average velocity of $10 \mathrm{~cm} / \mathrm{sec}$ and $<1$ day at $50 \mathrm{~cm} / \mathrm{sec}$. This rise time is negligible compared to the required isolation period of high-level radioactive waste. Ascent of basaltic magma can therefore be viewed as an instantaneous event. However, the auestion remains whether magma pauses and forms secondary storage chambers during ascent. Several lines of evidence suggest this occurs particularly for the basalts of the NTS area. First, the basalts of crater Flat are evolved from an inferred primitive parental composition. The atomic ratio of $\mathrm{Mg}$ to $\mathrm{Mg}+\mathrm{Fe}^{2+}$ ranges from 0.57 to $\sim 0.47$ and suggests fractionation of olivine, clinopyroxene, and amphibole (Vaniman and Crowe 1981). Such fractionation would readily occur in secondary storage chambers. Second, Kushiro (1980) has shown that the viscosity and density of basaltic melt are pressure dependent. In general, for an olivine tholeiite at liquidus temperature, there is a decrease in density and increase in viscosity with decreasing pressure. Referring to Eq. (1) for Newtonian melt with low Reynolds numbers, this will result in a decrease in ascent velocity with decreasing pressure (bubble-free regime). More importantly, due to the density dependence of the ascent equation, a velocity drop is likely at the mantle-crust density interface. This drop should cause a tendency to form magma storage chambers at that interface (Kushiro 1980). Such a conclusion is supported by Stolper and Walker (1980). They suggest that the density of residual 1 iquids produced by fractionation of olivine may control the ascent history of a basalt melt. A minimum in melt density is produced by the fractionation of olivine and clinopyroxene on a plot of density vs $\mathrm{Fe} /(\mathrm{Fe}+\mathrm{Mg})_{\mathrm{mol}}$, and this trough corresponds 
to the histogram peak of compiled basalt densities from sampling sites throughout the world. This suggests that the crust may act as a density filter, with the most compelling site being the crust/mantle density interface. By this means, ascending basalt is trapped at the base of the crust due to the abrupt decrease in the ascent velocity. Melt density is reduced through fractionation until the melt/crust density contrast allows continued ascent.

Supporting evidence for such a model is provided by the observations of Fedotor (1978) and Wood (1980). They suggest a relationship between cinder cone volume and/or cone growth rates and crustal thickness. Such a relationship would exist if basalt, following density filtering at the base of the crust, were erupted rapidly to the surface in narrow conduits that remain in hydrostatic equilibrium with their crustal roots. Magma eruption rates and cone volumes would therefore be determined by net magma ascent rates and the dynamics of the Strombolian eruption column; both are determined in part by magma oyerpressure, which is the integrated density difference between the magmatic column and the crustal column.

Finally, Fedotor (1981) has discussed the geometry of conduit feeder systems for volcanic centers from crustal through mantle depths. He suggests that the type of feeder is dependent on the magma flux rate, which is controlled primarily by the geotherm and the composition of the magma. Fedotor argues that the magma supply rate may determine the nature of activity of a volcanic center. Cyclic basaltic activity of the NTS region, which is characterized by formation of clusters of scoria cones, is typical of areas of low rates of magma supply. This type of activity is capable of forming deep crustal chambers (crust/mantle boundary) but the heat budget related to the magma flux rate is insufficient to allow formation of shallow crustal chambers (Fedotor 1981, Fig. 1).

V. SHALLOW BASALT INTRUSIONS: FCRM, DIMENSIONS, AND MAGMA PATHWAYS TO THE SURFACE

In this section, we examine the form of basaltic intrusions at and above probable burial depths of radioactive waste 1000 to $1500 \mathrm{~m}$ below the surface. The geometry of basalt intrusions and the geometry of the repository-magma zone of intersection will control the total volume of radioactive waste in contact with rising magma (Crowe 1980). The depth of waste-magma interaction 
will in part determine the amounts of waste transported to the surface by magma.

Basalt intrusions within the NTS region are of three forms, all emplaced at shallow levels: (1) irregular dike-like bodies present within scoria cones, (2) linear dikes exposed in country rock beneath scoria cones, and (3) sill-like intrusions emplaced at depths as much as $300 \mathrm{~m}$ beneath the surface.

A. Cone Intrusions

scoria cones in varying stages of erosional dissection have been mapped at a number of locations in the southcentral Great Basin. Scoria in the interior of cones near the vent conduit is commonly intruded by dikes (Fig. 2). These dikes, which are offshoots of conduit plugs, define both radial and concentric patterns with respect to the vent. Radial dikes dip steeply, commonly near vertical, with only minor changes in thickness along strike. Concentric dikes occur as arcuate intrusions (ring dikes). They vary markedly in thickness $(0.2$ to $5 \mathrm{~m})$, with irregular but generally inward dips. The dikes branch and coalesce along strike and have numerous smaller offshoots that may be discordant or concordant to bedding. Guttmann (1979) described dike intrusions within Strombolian cones of the Pinacate volcanic field. Kear (1957) noted the presence of necks (conduit plugs) and radial dikes in deeply dissected (Skeleton Stage) volcanic cones of the North Island of New Zealand. In general, cone intrusions form after the main stages of scoria cone growth (Crowe et al. 1981) and are limited to the cone intericrs. They therefore are not important to breeching of a buried repository by magma.

B. Linear Dikes

At several localities, notably in the northern Reveille Range of south central Nevada and along the silent Canyon ring-fracture system in the northern NTS, erosion has stripped through surface cones and exposed underlying feeder dikes in country rock. Here the numerous cone intrusions give way downward to one or several linear dikes. These dikes extend laterally as much as $2 \mathrm{~km}$ from the main vent of surface cones. They thicken adjacent to scoria cone vents and probably form plugs filling cone vents in the manner described by Delaney and Pollard (1975). These field relations suggest the roots of basalt centers in the NTS region are narrow elongate dikes (Fig. 3 ). c. Sill-Like Intrusions

Shallow basalt intrusions that form sill-like bodies in tuff and locally fed surface eruptions occur at two localities in the southern Great Basin. 


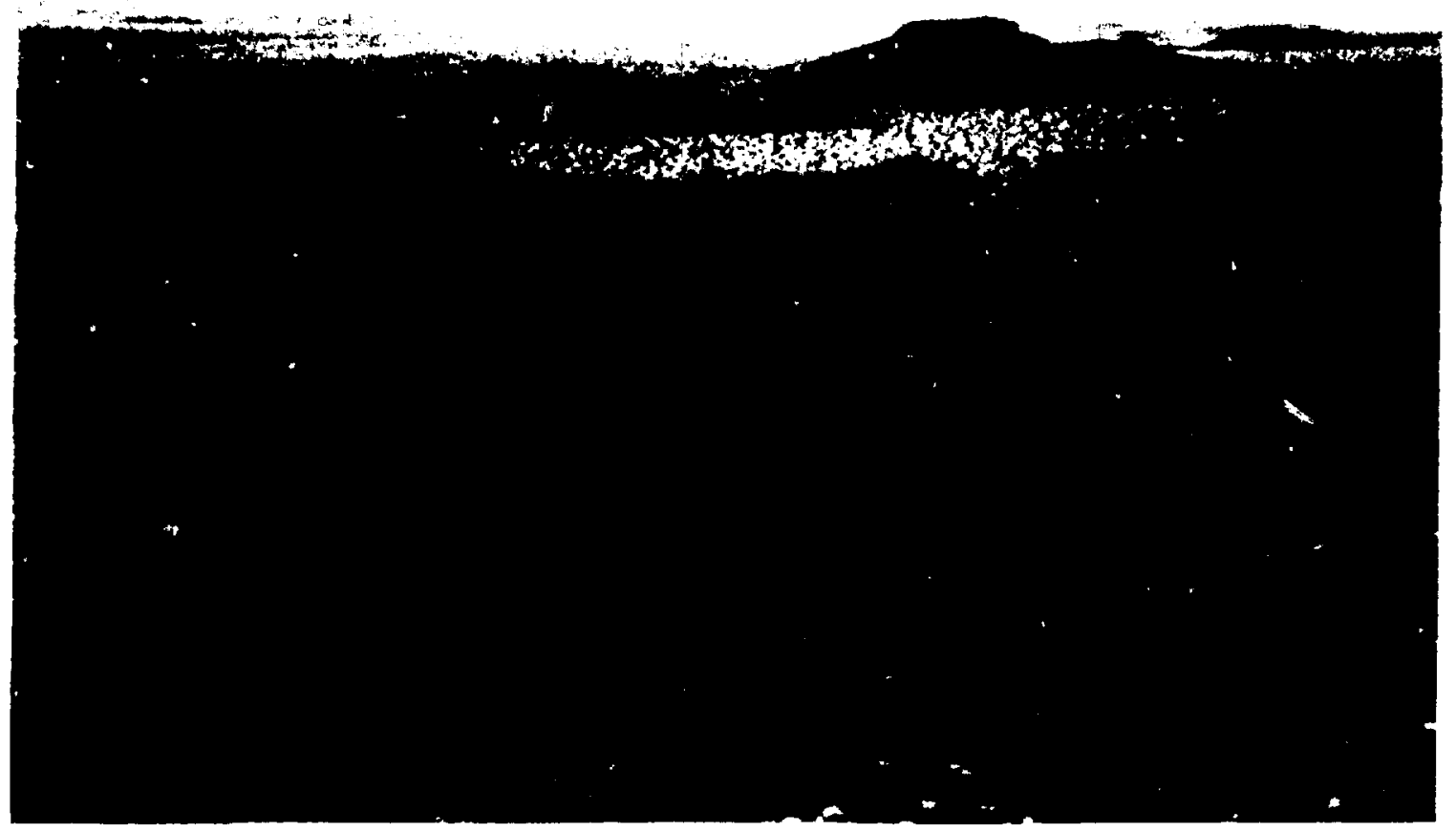

Fig. 2 .

Cinder cone remnant within the 3.7-Myr basalts exposed in the southeastern part of Crater Flat. The $y$-shaped dike in the center of the photograph is the remains of a former surface cinder cone; cone scoria surrounds the dike (low resistance to erosion). The small flat-topped mesa behind the dike is upheld by a concentric dike within another 3.7-Myr basalt cinder cone. Red Cone and Black Cone, two of a number of 1.2-Myr basalt centers in Crater Flat, are visible in the background.

These are the Paiute Ridge and Nye Canyon areas, both in the southeastern NTS area. The Paiute Ridge area has been mapped in detail by Byers and Barnes (1967) and will be described to illustrate the nature of this intrusion type.

The basalt intrusions, which have been dated at about 8.7 Myr, occur along and within an elongate north-northwest-trending series of gently tilted fault blocks of a graben system that extends much of the length of the Halfpint Range in the eastern NTS area. The intrusions themselves are confined to the northern part of the range (Fig. 4). They occur as a variety of 




Fig. 3.

Conduit plug exposed in the Paiute Ridge area. The plug is an area of cylindrical widening along a north-south trending dike injected along a normal fault. The northern continuation of the narrow dike is visible in the right-central part of the photograph. Note radial dike in the central part of the photograph.

forms: (1) elongate dikes that were injected along faults of a complex graben flanked by Paiute and Carbonate Ridges, (2) sill-like intrusions that branch from or tap off the elongate dikes, and (3) saucer-shaped or lopolithic intrusions within the floor of the main graben. The elongate dikes fill fault planes, and local offshoots of the dikes are displaced by faults. However, the majority of elongate dikes appear undisturbed by the faults. This suggests that the basalts were emplaced in part contemporaneously with, but largely following, faulting. The elongate dikes locally widen to form cylindrical plugs. The plugs flare or open upward and the margins are composed of vesiculated scoria, suggesting that the plugs mark the conduit vents 




Fig. 4 .

Basalt sill intruded at the Paintbrush Tuff-Ranier Mesa Member contact. The direction of magma movement during injection was from left to right as viewed on the photograph. The sill was fed from a linear dike that is exposed in the left center of the photograph.

of former surface cones. Basaltic magma locally vented at the surface, which is indicated by the presence of surface lava flows at two localities and by local cone scoria. Sheet-like intrusions occur at numerous localities within the northwest-trending graben. Some are sills that appear to follow the stratigraphic contact between the Paintbrush and Timber Mountain tuffs (Fig. 5); the majority are discordant, crossing the tuffs with contacts dipping inward at moderate to steep angles and toward the interiors of the intrusions. The above relations are consistent with the concentrated rise of basaltic magma within an elongate graben or rift-like fault system. Magma locally followed existing faults of the system, but in other areas it intruded in a complex, 


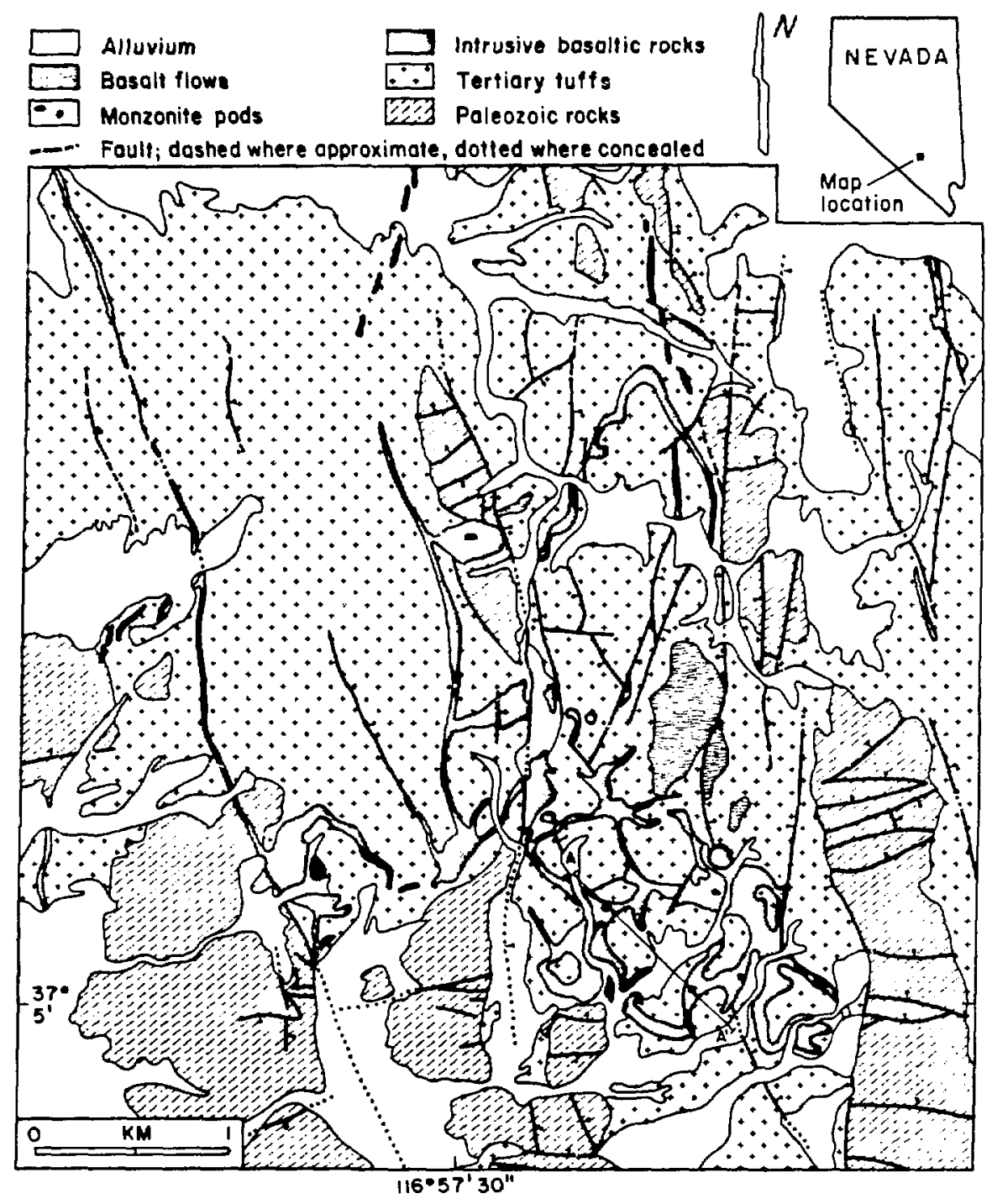

Fig. 5.

Generalized geologic map of the Paiute Ridge area (from Byers and Barnes 1967).

but generally lopolithic fashion, within downfaulted country rock. A minimum depth of intrusion can be approximated by assuming the Timber Mountain and Paintbrush Tuffs formed a near flat-lying ash-flow sheet during the time of basalt intrusion. Extrapolated thicknesses of these tuffs from adjacent areas yield a minimum intrusion depth (below the original surface) of about 200 to $300 \mathrm{~m}$. Field studies to date are insufficient to document the conditions of formation of the intrusions. However, several conditions probably favored 
their development. (1) They were emplaced within a graben with narrow lateral roof dimensions when the least principal stress direction $\left(\sigma_{3}\right)$ was horizontal (extensional faulting). (2) Bounding faults of the graben were filled by magma, facilitating lifting of the intrusion roof by magma pressure. This roof lifting may have been aided by a moderate yield strength of the magma due to a relatively high phenocryst content (Johnson and Pollard 1973). Modal petrographic analyses show a phenocryst content at the time of intrusion of about $20 \%$. (3) The rise of magma within low-density tuff country rock was slowed or stagnated due to a low volatile content of the magma. Field studies show the intrusions are vesicle free, indicating the basalt was intruded below the depth of volatile saturation.

The occurrence of intrusions below basalt centers, similar to those of the Paiute Ridge area, is extremely significant. Such intrusions could follow a repository tunnel complex, a likely stress void unless perfectly backfilled. Flooding of a respository tunnel by magma would greatly increase the amount of waste incorporated by magma. Should these contaminated magmas erupt, the potential for waste dispersal is likely to be substantial. Due to the importance of basalt intrusion forms, we have examined basalt feeder systems at numerous localities in the southern Great Basin. Several lines of evidence indicate that the majority of basalt centers are fed at depth by narrow linear dikes.

First, dikes are the most common intrusion form. A dike-like geometry at depth is required by the spacing of contemporaneous basalt centers along linear trends with significantly greater lengths than widths. An exploratory drill hole, $\mathrm{VH}-1$, was drilled in the central part of Crater Flat to investigate the subsurface geometry of the basalt field. The drill hole penetrated an intracanyon basalt flow buried in alluvium. No basalt intrusions were noted in either the alluvium or underlying section of tuff.

Second, calculated volumes of magma (density corrected to magmatic volumes) of individual basalt centers are on the order of $10^{-1}$ to $10^{-3} \mathrm{~km}^{3}$ (Table I). If we assume the eruptions are fed through a circular conduit with a radius of $2 \mathrm{~m}$ at an average velocity equal to the ascent rate $50 \mathrm{~cm} / \mathrm{sec}$, as described in the previous section, the surface effusion rate is $n 5 \mathrm{~m}^{3} / \mathrm{sec}$. This calculation ignores the increase in radius of the dike as the vent flares at the surface and the acceleration of magma due to exsolution of volatiles. 
TABLE I

SIZE PARAMETERS FOR THE BASALTIC CENTERS OF THE NTS REGION

Total

Magnetic

\begin{tabular}{|c|c|c|c|c|c|c|}
\hline Volcanic Center & $H(m)$ & $W(m)$ & $\begin{array}{c}\text { Cone volume } \\
\left(\mathrm{m}^{3}\right)\end{array}$ & $\begin{array}{c}\text { Flow volume } \\
\left(\mathrm{m}^{3}\right)\end{array}$ & Vents & $\begin{array}{l}\text { Volume } \\
\left(m^{3}\right)\end{array}$ \\
\hline athrop Wells & 140 & 690 & $1.7 \times 10^{7}$ & $1.6 \times 10^{?}$ & 3 & $5.7 \times 10^{7}$ \\
\hline Little Cone No. 1 & 43 & 360 & $1.5 \times 10^{7}$ & $3.0 \times 10^{6}$ & 1 & $6.2 \times 10^{5}$ \\
\hline Little Cone No. 2 & 27 & 220 & $3.4 \times 10^{5}$ & - & 1 & $7.8 \times 10^{5}$ \\
\hline Red Cone & 73 & 435 & $3.7 \times 10^{6}$ & $1.9 \times 10^{7}$ & 6 & $2.6 \times 10^{7}$ \\
\hline Black Cone & 121 & 525 & $2.7 \times 10^{7}$ & $4.4 \times 10^{7}$ & 3 & $1.0 \times 10^{\circ}$ \\
\hline leeping Cone No. 1 & 63 & 240 & $2.7 \times 1.06$ & $4.9 \times 10^{6}$ & 1 & $1.1 \times 10^{7}$ \\
\hline Sleeping Cone No. 2 & 70 & 562 & $5.8 \times 10^{6}$ & $8.1 \times 10^{6}$ & 1 & $2.1 \times 10^{\prime}$ \\
\hline
\end{tabular}

\footnotetext{
Magmatic volume is equal to the volume of the cone plus the volume of an inferred scoria sheet plus the lava volume corrected to magmatic density.
}

It assumes the effusion rates through the duration of an eruption are controlled by the average ascent rate and dike diameter at depth. This effusion rate $\left(5 \mathrm{~m}^{3} / \mathrm{sec}\right)$ is comparable to effusion rates of known basaltic eruptions, particularly, smal1-volume eruptions of Mt. Etna (for example, Wadge 1977). The calculation therefore suggests that the typical basalt eruptions of the NTS region could be fed entirely irom narrow dikes.

Third, the 1.2-Myr basalt cycle of Crater Flat consists of four basalt centers aligned along a slightly arcuate linear zone of trend $N 20^{\circ} \mathrm{E}$ and total extent of $11.5 \mathrm{~km}$ (Crowe and Carr 1980). This trend is parallel to the regional maximum stress direction (Carr 1974; Zoback and Thompson 1978). The similarity in K-Ar ages, magnetic polarity, and geochemistry suggest these basalts were emplaced during a single episode of magma generation (Vaniman and Crowe 1981). The total volume of material, corrected to magmatic volume,


basalts were fed from a single dike system with an average width of $4 \mathrm{~m}$ and an extent of $12 \mathrm{~km}$, this feeder dike would need to extend only to a depth of 5.8 $\mathrm{km}$ without widening to supply the total volume of surface eruptions. 
Fourth, geochemical data from the basalts of Crater Flat (Vaniman and Crowe 1981) and the NTS region (Hedge and Noble 1971) argue against shallow crustal contamination by assimilation. If basalt magma collected in a shallow chamber, it would likely melt and assimilate wall rocks of silicic tuff, the predominant surface rock type in the NTS region. The 1.1- and 0.3-Myr basaltic rocks of Crater $\mathrm{Flat}$ are particularly sensitive indicators of crustal contamination due to their low (10- to 45-ppm Rb) contents (Vaniman and Crowe 1981). These low $\mathrm{Rb}$ values argue strongly against any shallow crustal assimilation. Similar cases against crustal assimilation for basalts of the NTS region have been presented by Hedge and Noble (1971), based on plots of ${ }^{87} \mathrm{Sr} /{ }^{86} \mathrm{Sr}$ vs $\mathrm{Sr}$ and ${ }^{87} \mathrm{Sr} /{ }^{86} \mathrm{Sr}$ vs $\mathrm{Rb} / \mathrm{Sr}$.

Dike dimensions, where basalt dikes cut country rock, have been measured at a number of localities throughout the southern Great Basin. Dike widths range from 0.3 to $4 \mathrm{~m}$ and average $1 \mathrm{~m}$. Dike extents are difficult to measure without ideai exposure. In general, measured dike extents are probably less than the true length. Field measurements range from $<0.5$ to $4 \mathrm{~km}$. Fridleifsson (1977) notes that the width of the majority of dikes in Tertiary and Quaternary rocks of Iceland are within the range 0.5 to $5 \mathrm{~m}$. The average width of dikes, based on literature summaries of dike dimensions, is $2 \mathrm{~m}$ (McConnell 1967). The thickest measured dikes related to the Columbia River basalts are on the order of $5 \mathrm{~m}$ (Swanson et al. 1975). Fedotor (1978) suggests the aspect ratio of dikes is on the order of $10^{-2}$ to $10^{-3}$ (width/length), based on a presumed relationship between dike dimensions and wave velocity of intruded country rock. In a more comprehensive analysis, Pollard and Muller (1975) relate the form of a dike to gradients in the regional stress field and magma pressure during dike emplacment. They suggest the form of a dike is controlled by length, effective stress gradients, and average driving pressure and is therefore specific to local conditions. The fact remains, however, that measured dike dimensions at localities throughout the world are consistent with the aspect ratio of Fedotor (1978). This ratio $\left(10^{-2}\right.$ to $\left.10^{-3}\right)$ indicates dike lengths of $<1$ to $4 \mathrm{~km}$, based on measured dike widths of 0.3 to $4 \mathrm{~m}$. 
VI. BASALTIC VOLCANIC CENTERS: SURFACE CHARACTERISTICS AND DISPERSAL PATTERNS

Field studies in the NTS region, with emphasis on the younger basalt centers ( $<3 \mathrm{Myr}$ ), show similarities in the volume and nature of basaltic volcanism during the last 8.0 Myr (Crowe and Carr 1980; Vaniman and Crowe 1981). Several general patterns in the style or eruptive history of each center have been recognized. Each basalt center is composed of scoria cones of moderate size and associated lava flows. Lavas generally issued from flank vents at the base of cones or from arcuate fissure systems extending from the base of the cones. There is no consistent pattern of alternation between pyroclastic (cone-building) and lava-flow phases of eruption. In general, vigorous pyroclastic activity probably marks the initiation of an eruption and both accompanies and follows lava extrusion. There are, however, many exceptions. For example, older satellitic cones of the Lathrop Wells center overife and are therefore younger than the southernmost of two lava flows that vented from the flank of the main cone. In this case lava extrusion probably occurred early in the eruption history of the center. The terminal eruptive activity of the Black Cone center in Crater Flat was marked by infilling of the summit crater of the main cinder cone by thin lava flows to form a small lava lake.

Pyroclastic activity at basalt centers is not confined to a single vent; centers are composed of multiple vents, each marked by a scoria cone. In the NTS area, they are divided into two categories: large central cones, referred to as the main cones, and satellitic cones that are smaller than the main cone by a factor of 3 to 10 . The satellitic cones are consistently older than and located south of the main cones. This requires northward migration of active vent zones during an eruption cycle. The average distance of vent migration for the basalts of Crater Flat is $0.7 \pm 0.1 \mathrm{~km}$. The average number of cones at a single center, based on cone counts of seven Quaternary basalt centers in the NTS region, is about 2 to 3 cones. Thus field data suggest a general eruption pattern where the initial breakthrough of magma to the surface is marked by the development of an eruptive fissure with two or three loci of effusion. Each of these vents becomes the site of small scoria cones. As the eruption proceeds, activity shifts or concentrates at a singie vent that becomes the site of the main scoria cone. Such an eruptive sequence is suggested by calculations of dike cooling times. Delaney and Pollard (1981) 
note that the rate of inward propagation of a cooling front below solidus temperatures at the margins of dikes is controlled by dike thickness, magma velocity, distance from source, the temperature difference between magma and host rock, and magma velocity. Initial fracture channels or magma pathways during the opening stages of an eruption are probably narrow, allowing the magma to solidify quickly. As the eruption proceeds, a preferential channel should be established that grows in thickness due to expansion of the walls. The increased thickness allows longer cooling times and should keep the pathway open to magma. This pathway would thus become the major feeder for the main cone. Minor changes in location of surface vents is probably required by the high cooling rates of dikes in the shallow crust -- magma cooling times of approximately a few hours for dikes 2 m wide with associated magma velocities of $1 \mathrm{~m} / \mathrm{sec}$ have been calculated (Delaney and Pollard 1981). This suggests that expected nonsteady-state conditions during an eruption, such as the rate of upward movement of magma or temperature or viscosity changes, could allow complete solidification of magma within a feeder channel. Subsequent magma flow may parallel solidified dikes (composite dikes) or follow an independent pathway to the surface.

Scoria cones are composed of radially dipping deposits with dips ranging from 5 to $32^{\circ}$ and averaging 20 to $25^{\circ}$. The deposits consist of ash to blocksized $(0.06-$ to $>200-\mathrm{mm})$ pyroclasts and nonwelded bombs. The Red cone and Little Cones are scoria cones that are capped by concordant layers of agglutinated scoria composed of flattened, vesicle-poor bombs. These deposits formed during the final stages of pyroclastic activity when the eruption column decayed in height (a transition from Strombolian- to Hawaiian-type activity), probably due to decreasing gas content of the magma.

The repeated formation in time of scoria cones and associated lavas at basalt centers of the NTS indicates that the predominant eruption style is Strombolian. Strombolian activity refers to eruptions characterized by a pulsating eruption column that is composed of jets of gas and molten lava fragments that comprise the gas thrust phase (200 to $300 \mathrm{~m}$ in height). The eruptions occur in short bursts of a few seconds duration and, if continuous, may develop an accompanying convection column with heights on the order of several km. Characteristic deposits are scoria cones, scoria fall sheets, and lava flows (Macdonald 1973; Self et al. 1974; Chouet et al. 1974). Strombolian eruptions typically have low dispersal and fragmentation values (Walker 
1973a) in response to their limited eruption column heights and low mass eruption rates. Eruptions of this character tend to build steep, moderate-size cones with scoria sheets localized around the vents. Particle fragmentation is mainly governed by bursting of irregularly spaced bubbles in the vent (Walker 1973a; Blackburn et al. 1976).

Early eruptions of the Lathrop Wells Cone were phreatomagmatic or Surtseyan (Crowe and Carr 1980). These eruptions occur where rising magma encounters ground water or surface water. This type of activity is more explosive than Strombolian eruptions and causes greater particle fragmentation, resulting in a large percentage of fine-grained particles that may be dispersed regionally. Due to the smaller terminal fall velocities of finer particles, they are carried higher in the convection column of an eruption, thus allowing wide dispersal by prevailing winds. However, Surtseyan deposits in the NTS region have been recognized only at the Lathrop Wells center due probably to a shallower depth to the ground-water table and/or the possible occurrence of surface water within the drainage system at the Lathrop Wells center prior to eruptive activity. Surtseyan activity in the Yucca Mountain area, the site currently being investigated for a repository site (Dixon et a1. 1980), is unlikely. The surface topography is rugged with steep, well-established drainage gradients; ponding of surface water is unlikely. Additionally, the depth to the ground-water table in the northern part of Yucca Mountain is $\sim 450 \mathrm{~m}$. Lithostatic pressure at these depths should prohibit water from flashing to steam, a necessary process for phreatomagmatic or Surseyan eruptions.

Cone dimensions of the main scoria cone centers of Pleistocene age in the NTS region are listed on Table I [parameters measured following the techniques of Porter (1972) and Settle (1979)]. The basal diameter of main cones ranges from 0.22 to $0.69 \mathrm{~km}$; all are smaller than the mean diameter of $0.9 \mathrm{~km}$, determined for 910 cinder cones by Wood (1980). The height-to-width ratio of the NTS cones plot within the field of typical cones (Wood 1980) and follow the relationship first noted by Porter (1973a):

$$
H_{c}=0.18 \mathrm{~Wb} \text {, }
$$

where $H_{C}$ is the cone height and $W b$ is the basal diameter. The volume of cones from the NTS area is plotted vs the volume of associated lava flows on Fig. 6. 


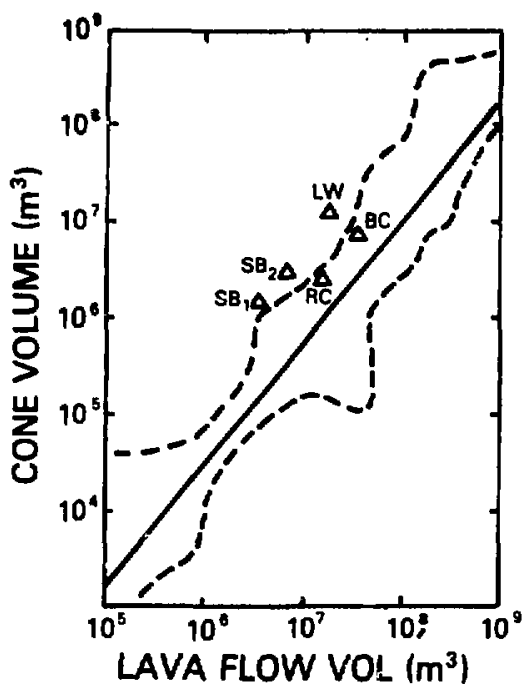

Fig. 6.

Plot of cone volume versus lava-flow volume for four Strombolian basalt centers of the NTS region. RC: Red Cone; BC: Black Cone; LW: Lathrop Welly Cone; $S B$ and $\mathrm{SB}_{2}$ : scoria cones of sleeping Butte. The dashed line encloses the data points of Wood (1980); the solid line is a calculated best fit linear regression line to fit the data points (Wood, 1980).

Wood (1980) has noted a correlation between cone yolume and flow volume with lava volumes generally greater by a factor of 5 to 100 . He suggests the relationship:

$$
\mathrm{CV}=0.00078 \times \mathrm{FV}^{1.26} \text {, }
$$

where $\mathrm{CV}$ is cone volume and $\mathrm{FV}$ is flow volume (uncorrected for density). The basalt centers of the NTS region plot close to the field of typical cone vs lava volume plots but are skewed consistently toward higher cone volumes (Fig. 6). This may reflect a low rise rate of magma relative to the rise rate of exsolved bubbles. Such a relationship would allow a higher ratio of gas to magma at fragmentation and produce a greater tendency for a pyroclastic vs a lava eruption (Wilson 1981). This is consistent with inferred low effusion rates based on short lava flow lengths.

Lava flows associated with Strombolian cones are consistently of blocky (aa) type, with one exception, the basalt of Buckboard Mesa. The Buckboard Mesa lavas (pahoehoe) are both the most voluminous and have the longest flow length of any lava in the region. Measured maximum flow lengths of seven Pleistocene lavas in the NTS region range from 0.6 to $1.9 \mathrm{~km}$ with a mean of $1.1 \pm 0.47 \mathrm{~km}$. Walker (1973b) has compiled statistics on lava lengths for large numbers of basalt flows. The average lava lengths of the NTS lavas are shorter than $91 \%$ of measured basalt lavas. Walker concluded that the most important variable affecting lava lengths is the rate of magma effusion through the duration of an eruption. Based on his published curves, the lengths of lava flows measured in the NTS region may have associated net effusion rates of $n 0.5 \mathrm{~m}^{3} / \mathrm{sec}$. There may be several problems with this suggested 
effusion rate. Walker measured flow lengths of composite lava flows and not individual flow units. The lava lengths are therefore affected by eruption magnitude (total volume) and duration, as well as eruption rate and variations in eruption rates with time (Wadge 1980). Additionally, Sparks and Pinkerton (1978) note the importance of the volatile content and degassing history of a magma, particularly in the development of yield strength and non-Newtonian behavior. Both factors may significantly affect lava flow lengths.

Perhaps the most important paraweters in the release of radionuclides if basalt magma penetrated a waste repository are the dynamics of Strombolian eruptions and the dispersal distances of scoria, particularly the fine ash fraction. The controlling mechanism of eruptions is the Strombolian eruption column, and it is likely that waste dispersal patterns will follow scoria dispersal patterns.

Strombolian scoria aprons are dispersed around and extend downwind of cinder cones. In the NTS region, most of the original scoria sheets have been removed by erosion; therefore, characteristics of scoria dispersal must be obtained from well-documented literature descriptions of Strombolian fall deposits. Numerous studies have been completed of the distribution of scoria fall sheets and particle-size variations within the sheets (for example, Self 1976; Booth et al. 1978; Heiken 1978). These studies generally show a systematic thinning and decrease in grain size of Strombolian fall deposits away from the source vent. The shape of isopleths drawn for selected characteristics of fall deposits is strongly controlled by the direction and velocity of low-level winds during an eruption. Contours are elliptical if the eruptitns were accompanied by winds of significant strength, the long axis of the ellipse being in the direction of prevailing winds. Strombolian scoria distribution during gentle or absent winds reflects the dynamics of the eruption column. Scoria dispersal and size contours are circular with the center of the circle at the vent. Figure 7 is a plot of 109 thickness vs distance from the source vent of well-characterized Strombolian scoria sheets. The plot shows the general thinning of the deposits with distance from the vent. The maximum thickness of the deposits is determined by the cone neight (a measure largely of the gas thrust column dynamics). The maximum distance of transport is determined by the maximum column height (convective phase) and the wind velocity. Inspection of Fig. 7 shows that the $10-\mathrm{cm}$ thickness 


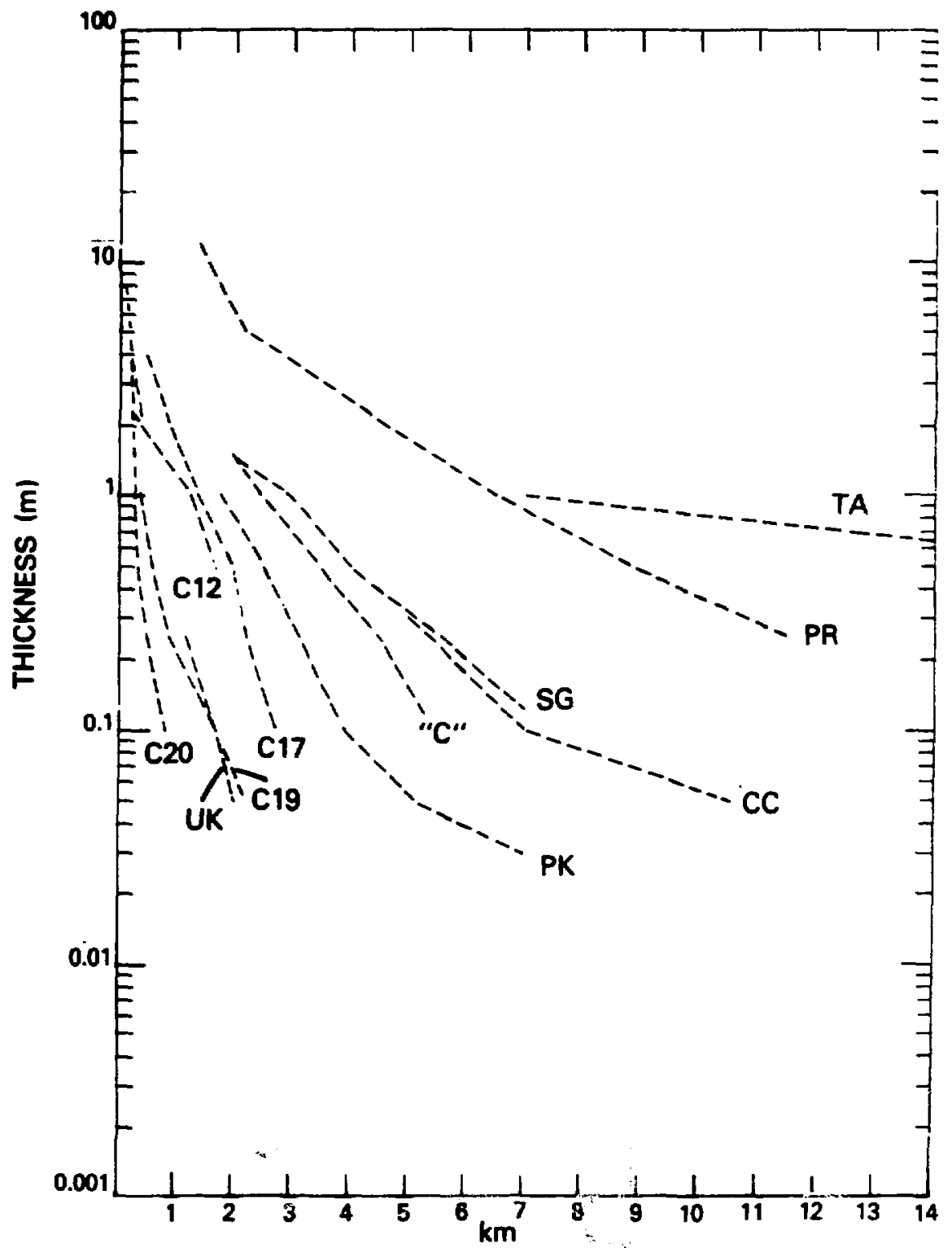

Fig. 7.

Plot of $\log$ thickness of basalt scoria deposits vs distance from source vents for Strombolian scoria sheets. TA: Walker et a1. (1982); PK Paricutin: Segerstrom (1950); SG and "C": Booth et al. (1978); C12, C17, C19, and C20: Self (1976); PK: Porter (1973b); UK: Self et al. (1980); CC: Heiken (is78); EK: Booth and others (1973).

isopach of typical Strombolian scoria sheets occurs at distances from the vent ranging from 2 to $10 \mathrm{~km}$. 
Grain-size characteristics of Strombolian deposits have been described by Walker and Croasdale (1972); they generally reflect the fragmentation mechanisms of the erupted magma. Fragmentation is controlled by the magmatic overpressure; the bubble spacing, size, and overpressure; and the depth of the fragmentation surface (Sparks 1978). Measured particle sizes range from meter-size blocks and bombs to ash $(<0.1 \mathrm{~mm})$. Typical median-diameter values of Strombolian deposits from grain-size studies range from -3.5 to -1.5 with sorting coefficients of about 0.5 to 2.0 , reflecting efficient particle sorting by fall velocity. This range, as pointed out by Walker (1971), is probably skewed to the finer sizes due to the problems of obtaining grain-size analyses of extremely coarse deposits.

VII. POTENTIAL DISPERSAL OF RADIOACTIVE WASTE BY STROMBOLIAN ERUPTIONS

The potential dispersal of waste by Strombolian eruptions can now be considered, assuming waste is fragmented and transported as discrete particles in magma. The waste particles could follow two pathways at the surface or volcanic vent: eruption with and incorporation in lava flows and eruption with pyroclastic fragments. We have assumed that the distribution of waste particles is similar to that of lithic (country rock) fragments and ignored, at this time, potential waste/magma geochemical reactions. Such reactions are unlikely to approach equilibrium in the short time span between incorporation and eruption, and the geochemical distribution of waste elements in magma would be extremely difficult to define.

The maximum distance of transport of waste particles in lava flows is determined by the lava flow length. Waste particles would be transported for distances ranging from near the vent to the distal edge of the lava flow, depending on the time of incorporation of the fragment during the eruption cycle and the specific lava flow path. As noted previously, average lava lengths for basalt centers of the NTS region are about $1 \mathrm{~km}$; the longest flow is $1.9 \mathrm{~km}$, although the lavas of the basalt of Buckboard Mesa traveled a maximum distance exceeding $5 \mathrm{~km}$. The average flow thickness of NTS lavas is estimated at about $12 \mathrm{~m}$. This compares with an average basalt lava thickness of $10 \mathrm{~m}$ (Walker 1973b). The average volume of lavas of NTS basalt centers is on the order of $10^{7} \mathrm{~m}^{3}$ (excluding the basalt of Buckboard Mesa). This corresponds to an average area of lava coverage, assuming an average flow thickness of $12 \mathrm{~m}$, of $2.5 \times 10^{6} \mathrm{~m}^{2}$. Waste could be contained in two types of aa lava 
flow material (with probable differing weathering or chemical leachability characteristics). These are rubbly flow breccia fragments with a generally high vesicularity, and dense flow material from the interior of aa flows.

Three lines of evidence suggest that the waste material may be incorporated preferentially in the pyroclastic component of an eruption. This conclusion is based on the assumption that waste is dispersed as solid particles and follows pathways similar to those of shallow country rock incorporated in erupting basalt magma. First, field observations at numerous localities in the southern Great Basin show that country rock fragments in lava are extremely rare. In contrast, such fragments are common in scoria deposits although the absolute amounts are extremely small. Second, solid particles incorporated in magma at depths above the exsolution depth of gas in a basalt magma are likely to be preferential sites of bubble nucleation (Sparks 1978). This should greatly increase the likelihood of incorporation of debris in the pyroclastic component of an eruption due to the mechanism of lava fragmentation and ejection of particles in a Strombolian eruption (bubble bursting at a fragmentation front). Finally, the upper surface of a body of magma ascending through the crust at depths above the level of volatile saturation will be an area of concentration of volatiles (assuming that bubble rise rates exceed magma rise rates). This will be the part of the magma that is the first to contact a repository and, due to the gas-charged nature, is more likely to form a pyroclastic eruption.

Pathways of individual waste particles in a Strombolian eruption column would be determined primarily by fragment fall velocity and local wind velocity. The factors controlling particle fall velocity have been reviewed by Walker et al. (1971). Three dispersal domains can be considered. These include the cone, the scoria sheet, and regional dispersal. Larger particles (several millimeters to meter size) are likely to be deposited within the scoria cone $(<1$-cone diam dispersal). Intermediate-size particles ( 1 to 10 $\mathrm{mm})$ are dispersed for distances equal to the maximum extent of measureable scoria fall deposits ( 5 to $10 \mathrm{~km}$; see Fig. 7 ). A fine-grained component $(<1$ $\mathrm{mm})$ may be carried significantly greater distances $(>10 \mathrm{~km})$. The exact distances would be dependent upon the height of the convective eruption column and the wind velocity. This component has not yet been measured in studies of Strombolian scoria and is effectively "missing." 


\section{A. Lithic Fragment Abundances}

The actual transport distances of waste dispersed in a Strombolian eruption column cannot be precisely determined due to the lack of data both on the size distribution of waste particles produced through breakage of waste by magmatic processes and on the detailed eruption mechanics. However, the maximum range of the volume of waste that may potentially be dispersed within each dispersal domain may be approximated by comparison to measured lithic fragment abundances. As noted previously, lithic fragments are country rock carried up from depth by rising and fragmenting magma. The depth of derivation of these particles is most likely controlled by the depth of volatile exsolution of a magma and the depth of the fragmentation front of a magmatic column. The depth of volatile exsolution is controlled by two parameters: the content and composition of volatile species $\left(\mathrm{H}_{2} \mathrm{O}, \mathrm{CO}_{2}\right.$, and $\left.\mathrm{Cl}\right)$ dissolved within a magma and lithostatic pressure. Some limits can be placed on magma-volatile contents (for example, Spera and Bergman 1980; Moore 1970). However, based on current data, the depth of exsolution cannot be determined with sufficient precision to bracket the depth of derivation of lithic fragments. It may range through depths of several hundred meters to several kilometers (Wilson and Head 1981; Spera 1981). It is therefore assumed to initiate below repository depths. The fragmentation front is the surface at which magma disrupts into scoria and gas. It is approximated by the point at which the gas-to-total volume ratio of a magma-gas mixture reaches 0.75 (Sparks 1978; Wilson and Head 1981). This depth is controlled in part by the magma-volatile content and exsolution depth but equally by the magma rise rate and the growth and rise history of bubbles in the magma. Calculations of this depth for a typical basalt (2-wt\% water) are less than $400 \mathrm{~m}$ (Wilson and Head 1981). This is in accord with field observations of exposed dikes and vents of basalt centers in the NTS region that indicate magma fragmentation at depths less than $200 \mathrm{~m}$. This depth of fragmentation is likely to be more shallow than the depth of burial by waste. Thus by inference, incorporation of lithic fragments in magma may occur through a depth range that exceeds the depth of burial of waste, all the way to the surface.

The abundance of 1 ithic fragments in basaltic scoria cones has been determined at a number of localities in the NTS region and in the San Francisco Yolcanic Field, Arizona. Results are summarized in Table II. In general, the abundance of lithic fragments in cone scoria ranges from nondetectable to as 
TABLE II

MEASUREMENTS OF LITHIC FRAGMENT ABUNDANCE IN STROMBOLIAN SCORIA CONES

\begin{tabular}{|c|c|c|c|c|}
\hline Locality & Type $^{a}$ & $\%$ by Area & Correction & $\%$ by Volume \\
\hline Lathrop Wells & $A$ & 0.013 & - & 0.009 \\
\hline Lathrop Wells & B & 0.33 & 0.10 & 0.022 \\
\hline Lathrop Wells & A & 0.048 & - & 0.032 \\
\hline Lathrop Wells & A & 0.057 & - & 0.038 \\
\hline San Francisco Field & $\mathrm{B}$ & 0.45 & 0.20 & 0.060 \\
\hline
\end{tabular}

\footnotetext{
${ }^{a}$ Type A measurements are localities where the distribution of lithic fragments is relatively uniform throughout cone scoria. Type B localities are areas of lithic-rich and lithic-poor scoria. These measurements are corrected by the estimated percentage of lithic-rich beds to the total scoria exposures.
}

great as 0.3 to $0.4 \%$ by area. Examinations of dissected cone scoria show that the distribution of lithic fragments is variable through the eruptive cycle represented by a scoria cone. Some scoria beds are free of lithic fragments whereas other beds contain fragments in amounts equal to the highest measured concentrations. Accordingly, we have made two types of measurements (Table II). Where existing exposures show a uniform distribution of lithic fragments in cone scoria, we have made direct measurements of abundances. Where fragment distribution is nonuniform, we have measured the upper range of lithic abundance and estimated (conservatively) the ratio of lithic-rich to lithicpoor scoria. The average for these calculations is $0.044 \pm 0.008 \%$ by area. This corresponds to a volume percent of 0.029 , based on a measured median diameter of $4.0 \mathrm{~mm}$ for lithic fragments and an estimated $6-\mathrm{mm}$ median diameter for cone scoria.

The depth of derivation of lithic fragments can be somewhat constrained through field studies. Thin-section examination of lithic fragments from the Lathrop Wells cone indicate the fragments are probably derived entirely from 
the Tiva Canyon Member of the Paintbrush Tuff, the capping unit of the gently dipping, underlying tuffs. Maximum thickness of the Tiva Canyon Member in this area is about $50 \mathrm{~m}$. Megascopic examination of lithic fragments in dissected cone scoria in the San Francisco Volcanic Field indicate derivation from the Kaibab Formation, the predominant surface rock type of the area. These data suggest shallow derivation of lithic fragments, with the depth of derivation probably being controlled by the depth of the magma fragmentation.

B. Waste Element Dispersal: Pyroclastic Component

Lacking detailed data on depth of lithic fragment incorporation, conservative estimates of the depth and area of fragment derivation can be used to allow the following calculations. It is assumed that the lithic fragments are incorporated from breakage and incorporation of dike walls during magma fragmentation from the base of a repository to the surface. Assume a tabular dike of 2- $\mathrm{m}$ width, a repository thickness of $10 \mathrm{~m}$ and a burial depth of the repository of $1000 \mathrm{~m}$. The wall surface area of the dike is $8 \times 10^{3} \mathrm{~m}^{2}$ and the area of contact between the dike and repository is $1 \%$ of the total dike wall area. The representative Strombolian center chosen for the calculations is the Lathrop Wells cone, the youngest and best preserved of the scoria cones in the NTS region. The volume of core scoria from this center is $1.7 \times 10^{7} \mathrm{~m}^{3}$; the calculated volume of lithic fragments contained in the scoria is $5400 \mathrm{~m}^{3}$. of this volume, $1 \%$ or ${ } 54 \mathrm{~m}^{3}$ is assumed to be derived from repository depths. Studies of volcanic cones in the NTS region have shown they are relatively resistant to erosion. The degree of erosion is strongly controlled by the local drainage gradient. The amount of scoria removed from the 1.2-Myr cones in the Crater Flat area ranges from $20 \%$ of the cone volume for cones in the southern part of Crater Flat (gentle:drainage gradient) to $90 \%$ removal for an isolated cone at the north end of Crater Flat. Choosing a middle value for the amount of cone removal and assuming similar rates of erosion in the future, $0.5 \%$ of the Lathrop Wells cone would be removed (dispersed) in a 10000 year period. The volume of cone material removed would be $8.5 \times 10^{4} \mathrm{~m}^{3}$, of which $27 \mathrm{~m}^{3}$ are lithic material, with about $0.3 \mathrm{~m}^{3}$ presumed to be derived from repository depths.

The original volume of scoria fall deposits associated with the cones of the NTS region (now removed by erosion) can be estimated by reference to studied Strombolian cones and scoria sheets. Self (1976) determined relative volumes of cones and scoria sheets of the most explosive Strombolian eruptions 
on the island of Terceira in the Azores. Scoria sheet-to-cone ratios range from $9: 1$ to 13:1. For less explosive events, the scoria sheet volume ranges from negligible to a scoria sheet-to-cone ratio of 9:1. The scoria sheet-tocone volume ratio calculated for Parecutin from the data of Segerstrom (1950) is about $4: 1$. The sheet-to-cone ratio for Sunset Crater, Arizona is $3.2: 1$ (Amos 1982). The products of typical Strombolian eruptions should fall within these ranges. Accordingly, a conservative ratio of $4.5: 1$ is assumed for the original basalt centers of the NTS region. The inferred volume of the scoria sheet associated with the Lathrop Wells cone is accordingly calculated as 7.6 $\times 10^{7} \mathrm{~m}^{3}$. Assuming a 1 ithic fragment content similar to that of the cone, the volume of lithics in the sheet is $2.4 \times 10^{4} \mathrm{~m}^{3}$ with $245 \mathrm{~m}^{3}$ from repository depths. Due to the uncertainty in assigning the ratio of the sheet-to-cone volume, we have attempted to define an average scoria sheet volume. Figure 8 is a plot of thickness vs total area for a number of well-studied Strombolian scoria sheets. The extrapolated volume for the Carra " $\mathrm{C}$ " fall deposits (Fig. 8) has been calculated. This deposit plots within the upper range of the Strombolian field of Fig. 8 and thus provides a conservative average value for the volume of scoria fall sheets. The volume of this representative Strombolian eruption is $3.0 \times 10^{7} \mathrm{~m}^{3}$, or smaller by $\backsim 60$ than the calculated scoria sheet of the Lathrop Wells center. This smaller sheet would contain $9.6 \times 103 \mathrm{~m}^{3}$ of lithic material of which $96 \mathrm{~m}^{3}$ may represent repository material. It is again important to determine whether this material is accessible to the surface environment within a 10 000-year period. Field studies of the Lathrop Wells and Black Rock Summit cones, Nevada, show that there are locally preserved remnants of their associated scoria sheets. The age of the Lathrop Wells cone is 300000 years and the age of the Black Rock Summit cone is poorly known, although it may, based on regional studies of Quaternary cones, be less than 100000 years. This suggests that a Strombolian scoria sheet is unlikely to be completely eroded within a 10 000-year period. However, detailed studies of the Strombolian scoria sheet of Sunset Crater, Arizona (Amos et a1. 1981; Amos 1982); indicate that approximately 11\% of the sheet has been eroded within a period of about 915 years, giving a yearly erosion rate of about $10^{5} \mathrm{~m}^{3}$. These are probably maximum erosion rates estimated from modifications of the geometry of thickness isopachs of the easily eroded distal edges of the sheet. Erosion rates are probably lower for the coarser and thicker, near-vent scoria deposits. Nevertheless, projected 




THICKNESS $(\mathrm{m})$

Fig. 8.

Log plot of area of coverage vs thickness of deposits of Strombolian scoria sheet deposits. Symbols are the same as for Fig. 6.

rates indicate complete erosion of the Sunset Crater scoria sheet within a 10 000-year period, and this is assumed for conservatism in the dispersal calculations.

Finally, an unknown amount of fine-grained material will be dispersed regionally. by wind turbulence. This material generally consists of particles finer than $63 \mu \mathrm{m}$, the lower limit of dry sieve analysis (4\$). Such particles have fall velocities of less than $0.1 \mathrm{~m}$ (Walker 1981). In general, Strombolian eruptions produce a low percentage of material smaller than $63 \mu \mathrm{m}$ due 
to the relatively low viscosity and generally Newtonian behavior of the magma. This is expressed quantitatively by the classification of Walker (1973). In general, the fragmentation value of Strombolian eruptions is <10\% (see also Wright et al. 1981; Walker 1981). Assuming this value represents an upper limit of the percent volume of fines in a Strombolian eruption, the total equivalent volume of fines for the Lathrop Wells center is calculated as $1^{7} x$ $10^{6} \mathrm{~m}^{3}$ of which $5.4 \mathrm{~m}^{3}$ could represent repository material. The total volume of fines can, however, be more closely approximated. Murrow et al. (1980) calculated a missing volume of fines of $6 \%$ of the total pyroclastic particle volume of a vulcanian eruption. This component can be presumed to be dispersed regionally. Particle fragmentation is more complete for vulcanian eruptions than Strombolian eruptions, which would result in a smaller percentage of fines in the latter type of eruption. Particle fragmentation of vulcanian eruptions is similar to Plinian eruptions; average fragmentation values largely overlap (Wright et al. 1981; Walker 1981). Assuming this is a valid reflection of the production of dispersed fines, a missing volume of $6 \%$ can be approximated for a Plinian eruption. Using the curves of Fig. 9, we can compute the equivalent volume of missing fines in a Strombolian eruption

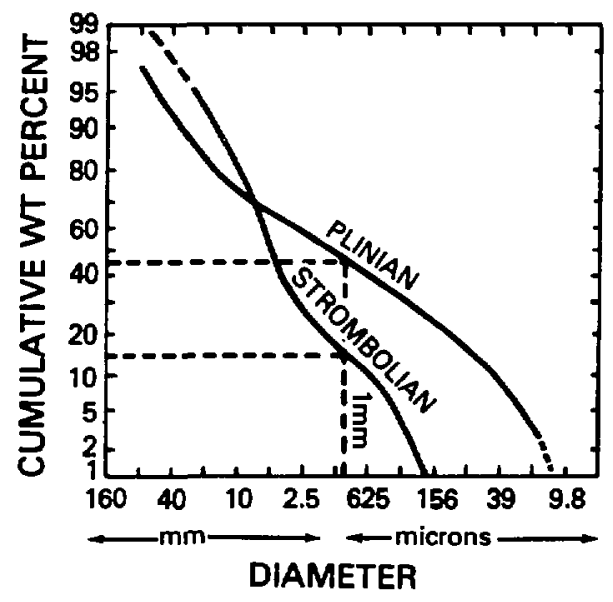

Fig. 9.

Plot of cumulative weight percent vs particle diameter for theoretical particle size distribution within Plinian and Strombolian eruption columns. Strombolian data from Self (1976) and unpublished data of Self. by extrapolating to the $63-\mu \mathrm{m}$ grain size. The resulting value is $2 \%$. This percent, calculated for the volume of the scoria cone and scoria sheet of the Lathrop Wells center, is $1^{9} \times 10^{6} \mathrm{~m}^{3}$. The 1 ithic fragment content of this missing component is $608 \mathrm{~m}^{3}$, of which $6.1 \mathrm{~m}^{3}$ represents repository material.

\section{DISCUSSIOFi}

The calculations of waste dispersal are clearly overgeneralized and assume that engulfed radioactive waste follows the same dispersal pathways as lithic fragments. Conservative calculations of the amounts of waste distributed 
indicate the major volume of accessible waste material would be deposited with a scoria sheet (96 to $245 \mathrm{~m}^{3}$ scoria sheet, $6.1 \mathrm{~m}^{3}$ regional, and $2.7 \mathrm{~m}^{3}$ scoria cone). Several important assumptions necessary to make these calculations need to be emphasized. It is assumed that the waste is carried mechanically by magma -- virtually no data are available on rates of geochemical reactions between waste and magma. It is assumed that lithic fragment and waste material are incorporated uniformly by erosion of dike walls from the repository depth to the surface. Field studies suggest that lithic material is derived predominantly from shallow depths $(<200 \mathrm{~m})$, which may be less than the burial depth of radioactive waste. The lithic fragment content within scoria fall sheets and within the fine-grained component of Strombolian eruptions is assumed to be similar to values measured for scoria cones (Table II). Limited field observations suggest a decrease in lithic fragment content with decreasing grain size. This is qualitatively supported by sieve analyses of fall deposits, but the percentages of lithic fragments in finer grained sieve components are below standard detection levels. Finally, the mechanism of intrusion of magma into a repository tunnel has not been considered. It is assumed that engulfed repository material corresponds directly to the volume of intersection of waste and magma. Assuming a feeder system of three dikes with a 2-m dike width and a repository width of $10 \mathrm{~m}$, the maximum volume of engulfed material is $120 \mathrm{~m}^{3}$. The exact volume of radioactive waste contained or accessible to this volume depends upon the detailed disruptive effects and the waste spacing within a repository tunnel. Both factors are beyond the scope of this work.

\section{ACKNOWLEDGMENTS}

Critical reviews of the manuscript were provided by $W$. Carr, $R$. Link, and S. Logan. The work was supported through the Nevada Nuclear Waste Storage Investigations .

\section{REFERENCES}

Amos, R. C., Self, S., and Crowe, B., 1981, "Pyroclastic activity of Sunset Crater: evidence for a large magnitude, high dispersal Strombolian eruption," EOS 62 , no. 45, 1085.

Amos, R. C., 1982 (in preparation). 
Anderson, O. L. and Grew, P. C., 1971, "Stress corrosion theory of crack propagation with applications to geophysics," Rev. Geophys. Space Phys. $15,77-104$.

Best, M. G. and Brimhall, W. H., 1974, "Late Cenozoic alkalic basaltic magmas in the western Colorado $\mathrm{plateaus}$ and the basin and range transition zone, U.S.A., and their bearing on mantle dynamics," Geol. Soc. Am. Bu11. 85, $1677-1690$.

Best, M. G. and Hamblin, W. K., 1978, "Origin of the Northern Basin and Range Province: implications from the geology of its eastern boundary," in Cenozoic Tectonics and Regional Geophysics of the Western Cordillera, R. B. Smith and G. P. Eaton, Eds., GeoT. Soc. Am. Mem. 152, 313-340.

Bjornsson, A., Johnson, G., Sigurdsson, S., and Thorbergsson, G., 1979, "Rifting of the plate boundary in North Iceland 1975-1978," J. Geophys. Res. 84, 3029-3038.

Blackburn, E. A., Wilson, L., and Sparks, R. S. J., 1976, "Mechanisms and dynamics of Strombolian activity," J. Geol. Soc. Lon. 132, 429-440.

Booth, B., Croasdale, R., Walker, G. P. L., 1978, "A quantitative study of 5,000 years of volcanism on Sao Miquel, Azores," Phil. Trans. R. Soc. Lon., Ser. A288, 271-319.

Booth, B. and Walker, G. P. L., 1973, "Ash deposits from the new explosion crater, Etna 1971," Phil. Trans. R. Soc. Lon. Ser. A274 147-151.

Brandsdottir, B. and Einarsson, P., 1979, "Seismic activity associated with the September 1977 deflation of the Krafla Central Volcano in Northeastern ICeland," J. Volcanol. Geotherm. Res. 6, 197-212.

Byers, F. M. Ir., Carr, W. S., Orkild, P. P., Quinivan, W. D., and Sargent, K. A., 1976, "1976 Volcanic suites and related cauldrons of the Timber Mountain-Oasis Valley Caldera complex, Southern Nevada," iS Geological Survey Professional Paper 919.

Byers, F. M. Jr. and Barnes, H., 1968, "Geologic map of the Paiute Ridge quadrangle, Nye and Lincoln Counties, Nevada," US Geological Survey Quadrangle Map GQ-577.

Carmichael, I. S. E., Nicholls, J., Spera, F. J., Wood, B. J., and Nel son, S. A., 1977, "High-temperature properties of silicate liquids: applications to the equilibration and ascent of basic magma," Phil. Trans. R. Soc. Lon. Ser. A286, 373-431.

Carr, W. J., 1974, "Summary of tectonic and structural evidence for stress orientation at the Nevada Test Site," US Geological Survey open-file report $77-176$.

Carr, W. J., et al., 1982 (in preparation). 
Chouets, B., Hamisevicz, N., and McGetchin, T. R., 1974, "Photoballistics of volcanic jet activity at Stromboli, Italy," J. Geophys. Res. 79, $4961-4976$.

Christiansen, R. L., Lipman, P. W., Carr, W. J., Byers, F. M. Jr., Orkild, P. P., and Sargent, K. A., 1977, "Timber Mountain-Oasis Valley caldera complex of southern Nevada," Geo1. Soc. Am. Bull. 88, 943-959.

Christiansen, R. L. and Lipman, P. W., 1972, "Cenozoic volcanism and plate tectonic evolution of the western United States; Part II, Late Cenozoic," Phi 1. Trans. R. Soc. Lon. Ser. A271, 249-284.

Crowe, B. M., 1980, "Disruptive event analysis: volcanism and igneous intrusion," Battelle Pacific Northwest Laboratory report PNL-2882.

Crowe, B., Self, S., and Amos, R. L., 1981, "Strombolian eruptive sequence," EOS 62 , no. 45,1084 .

Crowe, B. M., Johnson, M., and Beckman, T., 1982, "Calculation of the probability of volcanic disruption of a high-level radioactive waste repository within the Nevada Test Site Area," USA: Rad. Waste Mange. (in press).

Crowe, B. M. and Sargent, K. A., 1978, "Major-element geochemistry of the Silent Canyon-Black Mountain peralkaline volcanic centers, northwest Nevada Test Site: applications to an assessment of renewed volcanism," US Geological Survey open-file report 79-926.

Crowe, B. M. and Carr, W. J., 1980, "Preliminary assessment of the risk of volcanism at a proposed nuclear waste repository in the southern Great Basin," US Geological Survey open-file report 80-375.

Crowe, B. M., Vaniman, D., Carr, W. J., and Fleck, R. J., 1980, "Geology and tectonic setting of a neogene volcanic belt within the South-Central Great Basin, Nevada and California," in Abstr. with Programs, Geol. Soc. Am. Annual Meeting 93, 409.

Delaney, P. T. and Pollard, D. D., 1982, "Magma flow and solidification," Am. J. Sci. (in press).

Eaton, G. P., Wahl, R. R., Prostka, H. J., Mabey, D. R., and Kleinkopf, M. D., 1978, "Regional gravity and tectonic patterns: their relation to late Cenozoic epeirogeny and lateral spreading in the Western Cordillera," in Cenozoic Tectonics and Regional Geophysics of the Western Cordillera, R. B. Smith and G. P. Eaton, Eds., Geol. Soc. Am. Mem. 152, 51-92.

Ewart, A., Baxter, K., and Ross, J. A., 1980, "The petrology and petrogenesis of the Tertiary anorogenic mafic lavas of southern and central Queensland, Australia -- possible implications for crustal thickening," Contrib. Min. Pet. $75,129-152$.

Fedotov, S. A., 1981, "Magma rates in feeding conduits of different volcanic centers," J. Volcano1. Geotherm. Res. 9, 379-394. 
Fedotov, S. A., 1978, "Ascent of basic magmas in the crust and the mechanism of basaltic fissure eruptions," Int. Geol. Rev. 20, 33-48.

Fielder, G. and Wilson, L., 1975, Volcanoes of the Earth, Moon and Mars (St. Martin's Press, New York).

Fridleifsson, I. B., 1977, "Distribution of large basaltic intrusions in the Icelandic crust and the nature of the layer 2-layer 3 boundary," Geol. Soc: Am. 88, 1689-1693.

Guttmann, J. T., 1979, "Structure and eruptive cycle of cinder cones in the Pinacate volcanic field and the controls of Strombolian activity," $\mathrm{J}$. Geol. 87, 448-454.

Hedge, C. E. and Noble, D. C., 1971, "Upper Cenozoic basalts with high Sr $87 / 86$ and $\mathrm{Sr} / \mathrm{Rb}$ ratios, southern Great Basin, Western United States," Geol. Soc. Am. Bul1. 82, 3503-3510.

Heiken, G. H., 1978, "Characteristics of tephra from cinder cone, Lassen Volcanic National Park, California," Bul1. Volcanol. 41, 1-12.

Johnson, A. M. and Pollard, D. D., 1973, "Mechanics of growth of some laccolithic intrusion in the Henry Mountains, Utah, I," Tectonophys. 18 , 261-309.

Kear, D., 1957, "Erosional stages of volcanic cones as indicators of age," $N$. Z. J. Sci. and Tech., Sec. B. 38, No. 7, 671-682.

Knutson, J. and Green, T. H., 1975, "Experimental duplication of a highpressure magacryst/cumulate assemblage in a near-saturated Hawaite," Contrib. Min. Pet. 52, 121-132.

Kushiro, I., 1980, "Viscosity, density, and structure of silicate melts at high pressures, and their petrological applications," in Physics of Magmatic Processes, R. B. Hargraves, Ed. (Princeton University Press, Princeton), pp. 93-120.

Leeman, W. P., 1974, "Late Cenozoic alkali-rich basalt from the western Grand Canyon area, Utah and Arizona: isotopic composition of strontium," Geol. Soc. Am. 85, 1691-1696.

Lloyd, F. E. and Bailey, D. K., 1975, "Light element metasomatism of the continental mantle: the evidence and the consequences," in Physics and Chemistry of the Earth, L. H. Ahrens, J. B. Dawson, A. R. Duncan, and A. J. ErTank, Eds. (Pergamion Press, New York), pp. 389-416.

Logan, S. E., Link, R., Ng, H. S., Rockenbach, F. A., and Hong, K. J., 1982 , "Parametric studies of radiological consequences of basal tic volcanism," Sandia National Laboratories informal report SAND-81-2375.

Lowder, G. G., 1973, "Late Cenozoic transitional alkali olivine-tholeiitic basalt and andesite from the margin of the Great Basin, southwest Utah," Geol. Soc. Am. Bull. 84, 2993-3012. 
Maaloe, S., 1973, "Temperature and pressure relations of ascending primary magmas," J. Geophys. Res. 78, 6877-6886.

Macdonald, G. A., 1973, Volcanoes (Prentice-Hall, Englewood Cliffs, New Jersey).

McConnell, R. K., 1967, "Dike Propagation," in Economic Geology in Massachusetts, 0. C. Farquhar, Ed. (University of Massachusetts publications, Boston), pp. 97-104.

Miyashiro, A., 1978, "Nature of alaklic volcanic rock series," Contrib. Min. Pet. 66, 91-104.

Moore, J. G., 1970, "Water content of basalt erupted on the ocean floor," Contrib. Min. Pet. 28, 272-279.

Moore, J. G. and Krivoy, H. L., 1964, "The 1962 flank eruption of Kilauea Volcano and structure of the east rift zone," J. Geophys. Res. 69, No. $10,2033-2045$.

Murrow, P. J., Rose, W. I. Jr., and Self, S., 1980, "Determination of the total grain size distribution in a vulcanian eruption column, and its implications to stratospheric aerosol perturbation," Geophys. Res. Lett. 7., No. $11,893-896$.

Pinkerton, H. and Sparks, R. S. J., 1978, "Field measurements of the rheology of lava," Nature 276, 383-384.

Pollard, D. D. and Muller, O. H., 1976, "The effect of gradients in regional stress and magma pressure on the form of sheet intrusions in cross section," J. Geophys. Res. 81, 975-984.

Porter, S. C., 1973a, "Distribution, morphology, and size frequency of cinder cones on Mauna Kea Volcano, Hawai i," Geol. Soc. Am. Bul1. 83, 1923-1940.

, 1973b, "Stratigraphy and chronology of late quaternary tephra along the south rift zone of Maunoa Kea Volcano, Hawai," Bull. Geol. Soc. Am. 84, 1923-1940.

Prodeh1, C., 1970, "Seismic refraction study of crustal structure in the Western United States," Geol. Soc. Am. Bul1. 81, 2629-2646.

Prodeh1, C., 1979, "Crustal structure of the Western United States," US Geological Survey Professional Paper 1034.

Ramberg, H., 1968, "Model studies in relation to intrusion of plutonic bodies," in Mechanism of Igneous Intrusion, G. Newall and N. Rast, Eds. (Gallery Press, Liverpool), pp. 261-272.

Segerstrom, K., 1950, "Erosion studies at Paricutin State of Michoacan, Mexico," US Geol. Surv. Bul1. 965A.

Self, S., 1976, "The recent volcanology of Terceira, Azores," J. Geol. Soc. Lon. 132, 645-666. 
Self, S., Kienle, J., Huot, J-P., 1980, "Ukinrek maars, Alaska II: deposits and formation of the 1977 craters," J. Volcanol. Geotherm. Res. 7, 39-65.

Self, S., Sparks, R. S. J., Booth, B., and Walker, G. P. L., 1974, "The 1973 Heimaey strombolian scoria deposit, Iceland," Geol. Mag. VIII, 539-548.

Settle, M. E., 1979, "The structure and emplacement of cinder cone fields," Am. Sci. 279, 1089-1107.

Shaw, H. R., 1969, "Rheology of basalt in the melting range," J. Pet. 10 , 510-535.

Shaw, H., 1980, "The fracture mechanisms of magma transport from the mantle to the surface," in Physics of Magnatic Transport, R. B. Hargraves, Ed. (Princeton University Press, Princeton), pp. $201-264$.

Sparks, R. S. J., 1978, "The dynamics of bubble formation and growth in magmas: a review and analysis," J. Volcanol. Geotherm. Res. 3, 1-37.

Sparks, R. S. J. and Pinkerton, H., 1978, "Effect of degassing on rheology of basal tic lava," Nature 276, 385-386.

Sparks, R. S. J., Pinkerton, H., and MacDonald, R., 1977, "The transport of xenoliths in magnas," Earth Planet. Sci. Lett. 35, 234-238.

Spera, F. J., 1980, "Aspects of magma transport," in Physics of Magmatic Transport, R. B. Hargraves, Ed. (Princeton University Press, Prínceton), pp. 265-323.

Spera, F. J., 1981, "Carbon dioxide in igneous petrogenesis: II fluid dynamics of mantle metasomatism," Contrib. Min. Pet. 77, 56-65.

Spera, F. J. and Bergman, S. C., 1980, "Carbon dioxide in igneous petrogenesis, I," Contrib. Min. Pet. 74, 55-66.

Stewart, J. H. and Carlson, J. E., 1978, "Generalized maps showing distribution, lithology, and age of Cenozolc igneous rocks in the Western United States," in Cenozoic Tectonics and Regional Geophysics of the Western Cordillera, R. B. Smith and G. P. Eaton, Eds., Geol. Soc. Am. Mem. 152, 263-264.

Stolper, E. and Walker, D., 1980, "Melt density and average composition of basalt," Contrib. Min. and Pet. 74, 7-12.

Swanson, D. A., Wright, T. L., and Helz, R. T., 1975, "Linear vent systems and estimated rates of magma production and eruption for the Yakima basalt on the Columbia Plateau," Am. J. Sci. 275, 877-905.

Vaniman, D. and Crowe, B., 1981, "Geology and petrology of the basalts of Crater Flat: applications to volcanic risk assessment for the Mevada Nuclear Waste Storage Investigations," Los Alamos National Laboratory report LA-8845-MS. 
Vaniman, D. T., Crowe, B. M., and Gladney, E. S., 1982, "Petrology and Geochemistry of Hawaite lavas from Crater Flat, Nevada," submitted to Contrib. Min. Pet.

Wadge, G., 1977, "The storage and release of magma in Mount Etna," $\mathrm{J}$. Volcanol. Geotherm. Res. 2, 361-384.

Wadge, G.,1980, "Effusion rate and the shape of aa lava flow-fields on Mount Etna," Geology $\underline{6}, 503-506$.

Walker, G. P. L., 1964, "Geological investigation in Eastern Iceland," Bull. Volcanol. $27,351-363$.

J. GeoT. T9;, 696-714.

, 1973a, "Explosive volcanic eruptions-a new classification scheme,"Geol. Rundsch. 62, 431-466.

Ser. A274, $107-118$.

, 1981, "Generation and dispersal of fine ash and dust by volcanic eruptions," J. Volcanol. Geotherm. Res. 11, 81-92.

Walker, G. P. L., Self, S., and Wilson, L., 1982, "The 1982 eruption of Tarawera Volcano" (in press).

Walker, G. P. L., Wilson, L., and Bowel, E. L. G., 1971, "Explosive volcanic eruptions, I. the rate of fall of pyroclasts," Geophys. J. R. Astron. Soc. $22,377-383$.

Walker, G. P. L. and Croasdale, R., 1972, "Characteristics of some basaltic pyroclastics," Bul1. Volcanol. 35, 303-317.

Wilson, L., 1980, "Relationships between pressure, volatile content and ejecta velocity in three types of volcanic explosions," J. Volcanol. Geotherm. Res. $8,297-313$.

Wilson, L. and Head, J. W., 1981, "Ascent and eruption of basaltic magma on the Earth and Moon," J. Geophys. Res. 86, 2971-3001.

Wood, C. A., 1980, "Morphometric evolution of cinder cones," J. Volcanol. Geotherm. Res. I, 387-413.

Wright, J. V., Smith, A. L., and Self, S., 1980, "A working terminology of pyroclastic deposits," J. Volcanol. Geotherm. Res. 8, 315-336.

Yoder, H. S. and Tilley, C. E., 1962, "Origin of basalt magmas: an experimental study of natural and synthetic rock systems," J. Pet. $\underline{3}$, 342-532. 
Zoback, M. L. and Thompson, G. A., 1978, "Basin and range rifting in northern Nevada: clues from a mid-Miocene rift and its subsequent offsets," Geology $\underline{6}$, No. 2, 111-116. 